DOI: $10.17951 / \mathrm{m} \cdot 2018.3 .21-29$

\begin{tabular}{lcr}
\hline & ANNALES \\
& UNIVERSITATIS MARIAE CURIE-SKLODOWSKA & \\
LUBLIN - POLONIA & \\
VOL. III & SECTIO M & 2018 \\
\hline
\end{tabular}

Marta Michalczuk-Wlizło

Maria Curie-Skłodowska University in Lublin

marta.michalczuk-wlizlo@poczta.umcs.lublin.pl

ORCID ID: http://orcid.org/0000-0002-2107-8814

\title{
Preliminary Consideration of Complaints in the Light of the Case Law of the Constitutional Tribunal in Poland - Selected Issues
}

\section{Preliminary issue}

The institution of a constitutional complaint is now present in the Polish legal order for over twenty years. Thanks to its creation, the Constitution of the Republic of Poland became an act of a measurable significance for every individual. Citizens were granted a procedural guarantee protecting their rights and freedoms guaranteed in the Basic Law, and thanks to this the system of protection of fundamental rights was further enhanced.

The introduction of constitutional complaint meant that the Polish legislator granted the individuals the right to directly initiate protection of their constitutional rights and freedoms, by giving them the right to directly question the conformity of acts of law that concern these rights and freedoms with the constitution ${ }^{1}$.

1 See more: M. Michalczuk-Wlizło, Skarga konstytucyjna w Polsce, „Zeszyty Naukowe Wyższej Szkoły Ekonomii i Innowacji w Lublinie" 2007, nr 4. 
The introduction of the institution of a constitutional complaint undoubtedly contributed to more frequent statements of the Constitutional Tribunal, which formed explanations of substantive meaning and the principles for effective establishing and exercising the rights and freedoms guaranteed in the Basic Law. When analyzing the judicial activity of the Constitutional Tribunal regarding the constitutional complaint, it should be emphasized that in its course the particular preconditions for making a constitutional complaint were clarified, together with numerous concepts related to the functioning of the institution, such as "final settlement" or "constitutional freedoms or rights".

The judgments issued by the Constitutional Tribunal regarding constitutional complaints became an extremely important source of knowledge about the subject institution, and have undoubtedly contributed to a more proper functioning of the constitutional complaint in practice.

In the course of proceedings before the Constitutional Tribunal, as initiated by filing a constitutional complaint, a number of judgments were issued stating that the normative acts functioning in the Polish legal system are inconsistent with the Polish legal order. Therefore, the institution of a constitutional complaint contributed to the derogation from the Polish legal system of many unconstitutional laws and other normative acts.

When analyzing the period of our history in which the constitutional complaint was active, we must notice the intensification process of bringing the subject institution to the consideration by the Constitutional Tribunal, as well as the increase of the number of constitutional complaints brought in for substantive consideration.

What is also noticeable is the lowering number of incorrectly drafted constitutional complaints. In the initial period of functioning of this institution in the Polish legal order the most frequent formal and legal shortcomings included: lack of indication of specific constitutional right or freedom violated according to the petitioner, lack of definition of this breech, and specification, which act of law was complained against, lack of justification annexed to the complained, and also lack of entry fee (as long as this was applicable).

The institution in question turned out to be an important element in shaping the legal consciousness of the individual during the period of systemic transformation and in the initial stage of the formation of a democratic state of law. The constitutional complaint is perceived as a clear element of constitutional education of the society, which is reflected above all in the increasingly frequent reference to the constitutional court's case law when drawing up constitutional complaints. 


\section{Normative regulations and judicial practice}

The procedure in front of the Constitutional Tribunal regarding the constitutional complaint is regulated by the Act on Organization and Procedure of Constitutional Tribunal, and in the Internal Regulations of the Constitutional Tribunal, which define its internal proceedings. Although none of the above-mentioned acts of law contains a standard indicating expressis verbis the general principles of proceedings in front of the Constitutional Tribunal, it is, however, an analysis of the provisions of these acts and the reference contained in Art. 36 of the Act on Organization and Procedure of Constitutional Tribunal to the provisions of the Code of Civil Procedure, which allows us to indicate the basic principles that determine the subject proceedings. These include: availability, legality, openness, equality of parties, adversariality, collegiality, concentration of evidence, procedural formalism ${ }^{2}$.

In accordance with the principle of complaint set out in Art. $56 \mathrm{~s} .1$ of the Act on Organization and Procedure of Constitutional Tribunal, submitting a constitutional complaint constitutes the basis for instituting proceedings before the Constitutional Tribunal. The right to withdraw the complaint is vested in the applicant until the hearing begins (Art. $56 \mathrm{s.2}$ ). The use of it results in a decision to discontinue the proceedings taken in a closed session (Art. 59 s. 1 item) ${ }^{3}$.

The Ombudsman shall be notified of the receipt of a constitutional complaint and may, within 60 days of receipt of the notification, register his/her participation in the proceedings. If he or she decides to do so, he or she becomes a party in the proceedings. The Ombudsman declares his/her participation in the proceedings after considering that the complaint is justified and that the applicant should be supported, that is to act in the interest of his/her rights and freedoms. Formally, after such a notification, the Ombudsman submits a procedural letter to the Constitutional Tribunal stating the justification for support of the complaint.

Due to concerns about the inflow of a large number of complaints containing formal defects and unjustified complaints, the legislator, in order to secure the Tribunal's possibility of performing its tasks, introduced - in Art. 61 of the Act on Organization and Procedure of Constitutional Tribunal ${ }^{4}-$ the principle of preliminary examination of constitutional complaints. This stage is characteristic

2 Cf. A. Zieliński, Zakres stosowania przepisów k.p.c. w postępowaniu przed Trybunatem Konstytucyjnym, „Palestra” 1998, nr 7-8, p. 59 ff.

3 B. Szepietowska, Skarga konstytucyjna, „Gazeta Sądowa” 1998, nr 31, p. 9.

4 Patterned after Art. 49 of the 1997 Act on the Constitutional Tribunal. 
for procedure in case of constitutional complaint. The President of the Constitutional Tribunal issues an order on referring the constitutional complaint for preliminary examination in a closed session and appoints a judge. The judge of the Constitutional Tribunal, therefore, has the sole responsibility of deciding whether to pass a constitutional complaint to the next stage. After examining both formal and substantive premises, he or she issues a decision on granting or not giving the constitutional complaint its further procedural course. This decision requires justification.

If any formal defects are found, the judge calls for the deficiencies to be remedied within 7 days of the date of notification of petitioner. In the decision of 25 May 1999, reference no. Ts 95/98, the Constitutional Tribunal referred to the legal nature of the subject period. The view was held that the seven-day deadline set to supplement the formal defects is the statutory term, and therefore it is not legally permissible to extend or shorten the said deadline. The judge refuses to proceed with the complaint if:

1 ) the petitioner did not remedy formal defects within the prescribed period (7 days),

2) the complaint was filed after the deadline set in the Act on the Constitutional Tribunal,

3) the complaint is manifestly unfounded.

By introducing "manifested unfoundness" as one of the reasons for refusing to continue proceeding the constitutional complaint, the legislator provided for the possibility of making a preliminary substantive assessment (in a specified scope) of the submitted constitutional complaint at the stage of the preliminary proceedings before the Constitutional Tribunal ${ }^{5}$. In the justification of the decision of 16 August 2004, reference no. Tw 43/03, the Constitutional Tribunal explicitly stated that if the provisions referred to in the application as control standards do not relate to the norms challenged at all, then we are dealing with "manifested unfoundness". The statutory criterion of the foundness of a constitutional complaint imposes on the Constitutional Tribunal the obligation to asses, at the stage of initial proceedings, not only the fulfilment of formal criteria by the initiating act. The Constitutional Tribunal was also obliged by the legislator to examine whether the constitutional right or freedom to which the applicant is referring remains in a relevant relation with the normative act on the basis of

5 See: Discussion on the Decision of the Constitutional Tribunal of 16 August 2004, reference no. Tw 43/03, "manifestly unfounded" as a prerequisite of inadmissibility of the application or constitutional complaint. The principle of trust as the basis for the application of the regional council, the website of the Constitutional Tribunal: www.trybunal.gov.pl [access: 15.11.2018]. 
which the court or public administration body ultimately ruled on the rights or freedoms of the initiating party. It is not enough to quote the normative act itself. In the opinion of the Constitutional Tribunal, a constitutional complaint should be considered manifestly unfounded if it only questions a given normative act in a general fashion, without explicitly indicating the provision that violates the freedom or law guaranteed by the Basic Act ${ }^{6}$.

Not every groundlessness thus forms the basis for issuing an order not to submit the constitutional complaint to the next stage. According to the regulation of Art. 36 s. 3 of the Act on the Constitutional Tribunal, this should be manifested groundlessness, i.e. such that does not raise serious doubts and does not result only from the judge's subjective assessment. The decision of discontinuation of proceedings for a constitutional complaint can be appealed against by the petitioner, to the Constitutional Tribunal, within 7 days from the date of delivery of the decision (Art. 61 s. 5) . $^{7}$

In the opinion of the Constitutional Tribunal, a complaint against a decision to discontinue constitutional complaint proceedings, issued after the preliminary examination thereof, should be made by an attorney or barrister. The function of this procedure is to verify the position of the Constitutional Tribunal in respect of the compliance of the constitutional complaint with formal requirements and the admissibility of its substantive consideration. It should be consistently assumed that the duty of court representation in the scope of drawing up a constitutional complaint must also extend to activities that are leading to the verification of judgments of the Constitutional Tribunal falling in this phase of recognition of the constitutional complaint. Granting the petitioner the right to individually complaint against decisions of the Constitutional Tribunal, pertaining to the compliance of the constitutional complaint with formal requirements, would undermine the essence and purpose of the obligation to draft a constitutional complaint by an attorney or barrister. If we require legal knowledge of a professional in the phase of drafting the constitutional complaint, then it will be even more required for formulation of objections against a decision to discontinue the proceeding thereof ${ }^{8}$.

A complaint lodged within the aforementioned period shall be examined in a closed session by the adjudication panel appointed by the President of the

6 Decision of the Constitutional Tribunal of 24 January 1999, reference no. Ts 124/98.

7 Patterned after Art. 36 s. 4 of the Act on the Constitutional Tribunal.

8 Decision of the Constitutional Tribunal of 24 February 1998, reference no. Ts 19/97; see: The decision of the Constitutional Tribunal of 2 April 1998, reference no. Ts 15/98, Order of the Constitutional Tribunal of 20 May 1998, reference no. Ts 27/98, Order of the Constitutional Tribunal of 5 January 1999, reference no. Ts 105/98. 
Constitutional Tribunal ${ }^{9}$. As a result of the complaint, the Tribunal may issue a decision not to recognize the complaint. This decision is final, as no appeal is available (Art. $61 \mathrm{s.} 8$ of the Act) ${ }^{10}$.

Pursuant to Art. 57 of the Act on Organization and Procedure of the Constitutional Tribunal, if there are doubts as to the nature of the submitted writing, the President of the Constitutional Tribunal returns the writing to the sender or calls for supplementing the writing under pain of return, specifying a final deadline for this procedural activity. If, in response, the sender explains that the letter should be considered a constitutional complaint, then it is forwarded to preliminary consideration. In the absence of a response within the prescribed period, it is assumed that the writing in question was not a constitutional complaint and it remains unresolved. A writing, which has been corrected or supplemented has legal effects from the date of its submission ${ }^{11}$.

The President of the Constitutional Tribunal submits a constitutional complaint, which is not subject to formal obstacles or such that the proceeding was discontinued for, or appeal against its discontinuation was not granted, for consideration by an appropriate panel of judges, and appoints, on the motion of the Presiding Judge, a date for court session, notifying the participants of the proceedings.

\section{Summary}

In its jurisprudence, the Constitutional Tribunal often deals with the issue of manifested unfoundness of complaints, which are directed to the Tribunal. This manifested unfoundness is one of the conditions for issuing a decision not to proceed with the application, which results from the content of Art. 61 s. 4 point 3 of the Act on Organization and Procedure of the Constitutional Tribunal $^{12}$. The statement that the application is unfounded makes it impossible to proceed further before the Constitutional Tribunal. Due to the fact that the term

\footnotetext{
${ }^{9}$ Paragraph 10 s. 2 of the Regulations of the Constitutional Tribunal of 31 October 2001 (M.P. No. 41, item 668): Paragraph 10.2: "Complaint on not giving the application further course will be decreed by the president of the Tribunal for consideration by a panel of three judges of the Tribunal, in a closed session. The President of the Tribunal shall, in this case, appoint a bench, including a Presiding Judge and a Judge-Rapporteur".

${ }^{10}$ B. Szepietowska, Postępowanie ze skarga, [in:] Konstytucje Rzeczypospolitej Polskiej, red. L. Falandysz, B. Szepietowska, Warszawa 1998, pp. 127-128.

${ }^{11}$ Art. 57 s. 2 of the Act.

${ }^{12}$ More on the premises in: J. Królikowski, J. Sułkowski, Znaczenie przesłanki oczywistej bezzasadności dla dostępności skargi konstytucyjnej jako środka ochrony konstytucyjnych wolności i praw, „Przegląd Sejmowy” 2009, nr 5(94), p. 96 ff.
} 
of "manifested unfoundness" of complaints is a general clause, it proves very difficult to consider the fact of fulfilling the subject premise, without a thorough, rigorous analysis. That is why the jurisprudence of the Constitutional Tribunal is so extremely important, as it clarifies the meaning of particular indefinite terms. The use of indefinite terms by the legislator is a deliberate procedure aimed at making the law interpretation process more flexible ${ }^{13}$. The legislator has deliberately failed to define the authentic concept in question, since it was reasonable to consider that at each stage of the preliminary examination of a constitutional complaint, the Constitutional Tribunal will assess, whether there were premises to refuse to consider the complaint further, and if so, which ones, of the ones listed in the Act.

One of the elements of "manifested unfoundness" is, for example, not fulfilling all the premises necessary to effectively file a complaint, as listed in Art. $53 \mathrm{s.} 1$ of the Act ${ }^{14}$ or indication as a model of control of these regulations of the Act, which do not individually form the constitutional rights and freedoms of the applicant ${ }^{15}$. Unfoundness must take the qualified form of "manifested", i.e. visible at first glance, indisputable and undeniable ${ }^{16}$.

According to the Tribunal, a complaint shall also be deemed unfounded when the applicant fails to indicate specific freedoms or rights that were infringed directly by the regulation questioned by the complaint. Where the applicant quotes the general rules of law it is not identical with precise, specific definition of these rights, and due to the aforesaid such a complaint shall be ruled unfounded ${ }^{17}$. Furthermore, the premise of unfoundness is also filled in by a complaint, where

${ }^{13}$ Cf. E. Łętowska, Interpretacja a subsumcja zwrotów niedookreślonych i nieostrych, „Państwo i Prawo" 2011, nr 7-8, p. 18.

${ }^{14}$ In accordance with the applicable law, the constitutional complaint includes: 1) defining the challenged provision of the Act or other normative act on the basis of which the court or public administration authority has finally ruled on the freedoms, rights or duties of the applicant, as specified in the Constitution and in relation to which the applicant seeks to declare their non-compliance with the Constitution; 2) an indication of which constitutional freedom or right of the applicant, and how - according to the applicant - were violated; 3) justification of the allegation of non-compliance of the challenged provision of the Act or other normative act, with the indicated constitutional freedom or right of the applicant, together with arguments or evidence supporting it; 4) presentation of the facts; 5) documents proving the date of delivery of a judgment, decision or other settlement; 6) information whether the judgement, decision or other settlement was subject to extraordinary appeal.

${ }^{15}$ Cf. The decision of the Constitutional Tribunal of 19 November 2014, reference no. Ts. $236 / 14$.

${ }^{16}$ Cf. D. Knaga, Oczywista bezzasadność skargi konstytucyjnej, „Przegląd Prawa Konstytucyjnego" 2017, nr 1(35), p. 16.

17 The decision of the Constitutional Tribunal of 17 July 2018, reference no. Ts 171/17. 
the applicant did not indicate any provision of the Act or another normative act whose constitutionality he or she contests ${ }^{18}$. The Tribunal also refused to proceed with a complaint, where the applicant did not indicate the final decision issued by a court or administrative body, and only referred to individual interpretations in the field of tax law, which in Tribunal's opinion did not form a final decision within the meaning of Art. 79 s. 1 of the Constitution of the Republic of Poland ${ }^{19}$.

As is clear from the case law of the Constitutional Tribunal, the notion of groundless complaints is very extensive, multithreaded, and the significant number of complaints that are not submitted to further consideration forms a justification for their control at the initial consideration stage.

\section{Bibliography}

- Act of 1 August 1997 on the Constitutional Tribunal (Journal of Laws, no. 102, item 643).

- Act of 30 November 2016 on Organization and Procedure of Constitutional Tribunal (Journal of Laws 2016, item 1157).

- Constitution of the Republic of Poland of 2 April 1997 (Journal of Laws, no. 48, item 483).

- Decision of the Constitutional Tribunal of 24 February 1998, reference no. Ts 19/97.

- Decision of the Constitutional Tribunal of 2 April 1998, reference no. 15/98.

- Decision of the Constitutional Tribunal of 20 May 1998, reference no. Ts 27/98.

- Decision of the Constitutional Tribunal of 5 January 1999, reference no. Ts 105/98.

- Decision of the Constitutional Tribunal of 24 January 1999, reference no. Ts 124/98.

- Decision of the Constitutional Tribunal of 16 August 2004, reference no. Tw 43/03.

- Decision of the Constitutional Tribunal of 19 November 2014, reference no. Ts 236/14.

- Decision of the Constitutional Tribunal of 17 July 2018, reference no. Ts 171/17.

- Decision of the Constitutional Tribunal of 26 July 2018, reference no. Ts. 106/17.

- Decision of the Constitutional Tribunal of 14 August 2018, reference no. 32/17.

- Knaga D., Oczywista bezzasadność skargi konstytucyjnej, „Przegląd Prawa Konstytucyjnego" 2017, nr 1(35).

- Królikowski J., Sułkowski J., Znaczenie przesłanki oczywistej bezzasadności dla dostępności skargi konstytucyjnej jako środka ochrony konstytucyjnych wolności i praw, „Przegląd Sejmowy” 2009, nr 5(94).

- Łętowska E., Interpretacja a subsumcja zwrotów niedookreślonych i nieostrych „Państwo i Prawo" 2011, nr 7-8.

${ }^{18}$ In the decision of 26 July 2018, reference no. Ts 106/17, the Tribunal stated that the applicant has failed to indicate any provision of the Act or other normative act in the complaint. The content and justification of this procedural writing do suggest that it questions an individual act applying the law, i.e. the decision by the Court of Appeal - and thus the applicant has wrongly indicated the subject of constitutional complained, thus failing to fulfill the premises listed in Art. 79 s. 1 of the Constitution and the Act.

19 The decision of the Constitutional Tribunal of 14 August 2018, reference no. Ts 32/17. 
- Michalczuk-Wlizło M., Skarga konstytucyjna w Polsce, „Zeszyty Naukowe Wyższej Szkoły Ekonomii i Innowacji w Lublinie", 2007, nr 4.

- Regulations of the Constitutional Tribunal of 31 October 2001 (M.P. no. 41, item. 668).

- Szepietowska B., Skarga konstytucyjna, „Gazeta Sądowa” 1998, nr 31.

- Szepietowska B., Postępowanie ze skarga, [in:] Konstytucje Rzeczypospolitej Polskiej, red. L. Falandysz, B. Szepietowska, Wydawnictwo Zrzeszenia Prawników Polskich, Warszawa 1998.

- Website of Trybunał Konstytucyjny, www.trybunal.gov.pl [access: 15.11.2018].

- Zieliński A., Zakres stosowania przepisów k.p.c. w postępowaniu przed Trybunatem Konstytucyjnym, „Palestra” 1998, nr 7-8.

Summary: The constitutional complaint has been functioning in the Polish legal system since 1997. The decisions issued by the Constitutional Tribunal regarding a constitutional complaint have become a very important source of knowledge about the subject institution, and have undoubtedly contributed to a more correct functioning of the constitutional complaint in practice. The purpose of the article is to analyze the preliminary consideration of complaints with particular consideration of the "manifested unfoundness" condition.

Keywords: constitutional complaint; Constitutional Tribunal; preliminary consideration; constitutional law

\section{Wstępne rozpoznanie skarg w świetle orzecznictwa Trybunału Konstytucyjnego w Polsce -} wybrane aspekty

Streszczenie: Skarga konstytucyjna funkcjonuje w polskim porządku prawnym od 1997 roku. Orzeczenia wydane przez Trybunał Konstytucyjny w przedmiocie skargi konstytucyjnej stały się bardzo ważnym źródłem wiedzy na temat przedmiotowej instytucji, a także niewątpliwie przyczyniły się do bardziej prawidłowego funkcjonowania skargi konstytucyjnej w praktyce. Celem artykułu było przeprowadzenie analizy etapu wstępnego rozpoznania skarg ze szczególnym uwzględnieniem przesłanki „oczywistej bezzasadności”.

Słowa kluczowe: skarga konstytucyjna; Trybunał Konstytucyjny; wstępne rozpoznanie; prawo konstytucyjne 